\title{
Enhancing learners' reading habits through reading bags at secondary schools
}

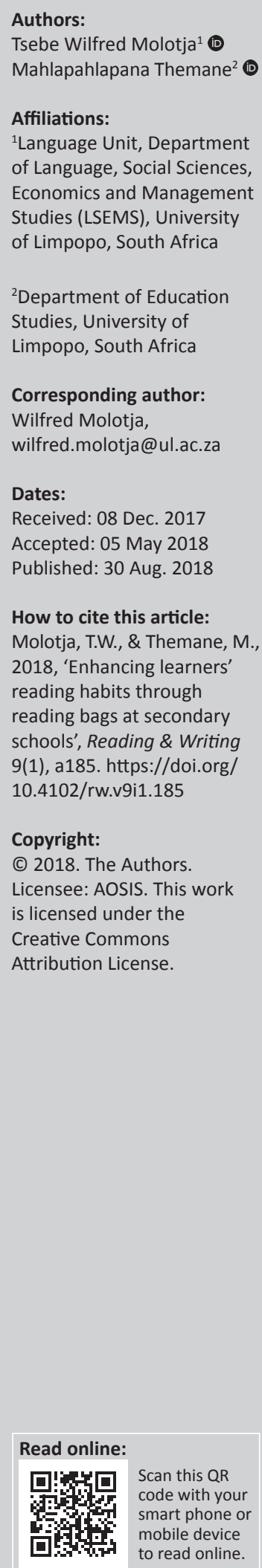

\begin{abstract}
The importance of getting children off to a good start in reading cannot be overstated. Successful academic performance at primary and secondary school level is partly dependent on the ability to read. It is believed that good learners are those who are proficient in reading. However, many learners are struggling to read and, therefore, struggle to academically succeed in other subjects. The problem of not being able to read transcends negatively on learners' academic achievements. This study proposes a strategy towards motivating learners in developing better reading habits through the distribution of reading bags. The mixed-method approach was adopted in conducting this study. Learners' reading strategies were first identified by administering a survey on reading strategies. About 14 student-educators volunteered in distributing the questionnaires at their respective schools during their teaching practice sessions. The questionnaires were distributed to 155 learners who voluntarily participated in the study. Data were analysed using the Statistical Package for Social Sciences (SPSS) software for descriptive statistics. The results indicated that most of the learners use global reading strategies, with the least utilising the problem-solving strategies and the support reading strategies. The researchers recommend the usage of reading bags as a strategy to motivate learners to develop good reading habits, which will then lead to the usage of all three strategies, in particular, the problem reading strategies.
\end{abstract}

\section{Introduction and background}

It is globally known that children usually struggle with reading in English as a second language at various grades of their schooling (Chizwina 2011; Gallagher 2009; Mokhtari, Reichard \& Gardner 2009). This contributes negatively towards their academic success. Research indicates that success in academic performance hinges on the ability to read (National Reading Strategies 2008). The results from the surveys conducted in the National Reading Strategy indicated shockingly low levels of reading ability across the country in South Africa (National Reading Strategy 2008:4). In addition, the results from studies conducted by the Proficiency in International Reading Literacy Study (PIRLS 2016) and the Annual National Assessment (2014) indicate that there are low literacy levels among Grades 4 and 5 learners. This is contrary to the aims of the National Department of Basic Education. The aim of the National Development Plan is that children should have access to, and benefit from a highquality education system, which hinges on the ability to read. Therefore, the problem of children not being able to read becomes a national one and may impede the achievement of developmental goals as set in the National Reading Strategies (2008) and the National Development Plan (2011:267).

In arguing for the importance of being able to read, Palani (2012:91) states that being able to read effectively is the most important avenue of effective learning and academic achievement. It is therefore necessary that learners engage in good reading habits to improve their reading ability. Learners have to be introduced to pleasure reading to form good reading habits, which will then transcend into improved academic reading skills (Scott \& Saaiman 2016:1). It is at primary level that learners need to be exposed to reading for pleasure, in developing academic reading skills, which are to be applied in different schooling subjects in secondary and tertiary institutions. However, this ideal is not true for most South African children by the time they complete their primary schooling. As part of the interventions to remedy this lack of desire to read for pleasure, we sought to make use of reading bags as a strategy for promoting reading. Therefore, the purpose of this study was to investigate the use of reading bags to inculcate the love for reading among secondary school learners living in impoverished social settings. 


\section{Reading skills and extensive reading}

Many definitions have been suggested for reading, which may apply differently to reading contexts. Arkarsu and Harputlu (2014) view reading as a complex processing skill in which the reader interacts with the text in order to create meaning. The possession of good reading skills is therefore a key towards accessing information and deciphering meaning out of texts (Ralenala 2003; Chiang 2016:1). Chiang (2016) argues that for the development of good reading skills and habits, learners should be exposed to reading at an earlier age. The ability to read and comprehend is critical not only for lifelong learning but also for adequate functioning in society (McNamara 2007:28).

Literature has also linked the development of reading skills to extensive reading (Day \& Bamford 2004:5; Stoller 2015). Day and Bamford (2004) explain extensive reading as focussing on the rapid reading of books. This means that learners should be exposed to a lot of reading, either reading for pleasure or reading academic books. Extensive reading has benefits for students in academic contexts. Grabe (1991) states that it helps students in their development of automaticity, enhances their background knowledge, improves comprehension skills, as well as promotes confidence and motivation (Ralenala 2005). In addition to the above risks, frequent reading also has a positive impact on learners' acquisition of new vocabulary (Acheaw \& Larson 2014; Chiang 2016; Scott \& Saaiman 2016:3). Nhapulo, Simon and Van Herreweghe (2017:1) claim that the aim of extensive reading is to 'cultivate' students' ability to read a long text and still gain understanding and to read and understand words and sentences at first glance without the need to reread.

\section{Reading habits and reading strategies}

Reading habits are defined as well planned and deliberate patterns of study which have attained a form of consistency on the part of students toward understanding academic subjects and their performance (Acheaw \& Larson 2014:12).

A study by Wulundari (2016) found that there is a positive significant correlation between students' reading habits and their comprehension levels. When reading habits become internalised and occur subconsciously, then the reading process becomes a meaningful one. Walundari (2016) argues that the development of self-concept and good reading habits can foster an improvement in academic achievement. Students with good reading habits tend to comprehend easier than those with poor reading habits. The more students are exposed to reading different texts, the more they develop positive attitudes towards reading. The meaning-making process involved in reading will only become successful with the use of appropriate strategies.

\section{Reading bags as a reading promotion strategy}

A reading strategy is defined as a 'tool or plan for facilitating and extending comprehension' (McNamara 2007; Molotja 2016; Routman 2003). Henia (2003) describes a strategy as a conscious and flexible plan that readers apply to particular texts and tasks. For example, McNamara (2007:6) defines reading comprehension strategies as: '... a cogntive or behavioural action that is enacted under particular contextual conditions, with the goal of improving some aspect of comprehension'. In addition to the above, Cekiso and Madikiza (2014:1) view reading strategies as 'specific actions, behaviours, steps or techniques that learners use to improve their progress in comprehending, internalising and using a second language'.

Reading bags are seen as a strategy for promoting reading among learners. Their use is not only good for developing comprehension but also for making learners relax. Acheaw and Larson (2014:9), argue that 'students who read magazines at intervals learn to relax, cool their brain, avoid mental fatigue and live a disciplined life in the school'. This demonstrates the influence that reading novels and other texts might have on learners. Reading bags may be used in addressing the problem of inadequate reading and limited vocabulary (Stone 2013:2). It is through the exposure to reading novels and other texts that learners acquire the skills to summarise, synthesise, integrate and critically analyse information from texts. Learners need to have the skills to be able to read fluently and critically (Boakye 2017; Grabe \& Stoller 2002; Molotja 2016; Shafie \& Nayan 2011; Stone 2013). The use of reading bags may help to develop these skills among learners. The study by Greene and Serro (2015) focussed on motivating students to read through the use of literacy bags. The study found that there is a positive correlation between the usage of literacy bags on one hand and professional reading and critical reading on the other.

The use of reading bags in the English class can serve as a motivating factor to learners (Greene \& Serro 2015:2). English teachers do have some influence over their learners in the classroom, and as such can instil positive motivation in their learners when they introduce good reading habits in the form of reading novels. They serve as role models and literary sparks for learners (Greene \& Serro 2015:2).

Students need to be aware of different reading strategies and how they can use these strategies in different academic reading contexts.

\section{Metacognitive reading strategies}

There are various strategies which can be employed in developing learners' reading habits. Some of these strategies are known as metacognitive strategies. These are selfregulating thoughts that monitor cognition, while cognitive strategies process the language for the task. In view of the 
discussion made above, metacognition is, therefore, very important across the curriculum and an emphasis on metacognition needs to accompany instruction in each of the school disciplines (Negretti \& Kuveeta 2011:23; Pammu, Amir \& Maasum 2014:2; Zohar \& Dori 2012:1). For learners to acquire these reading strategies, they should have developed the positive attitude towards reading. In addition to the above, Mokhtari and Reichard (2002) and Mokhtari and Sheory (2002) argue that it is important for learners to be aware of their metacognitive reading strategies, which lead to better reading comprehension strategies. Stone (2013) argues that the teaching of reading comprehension strategies will therefore include generating one's own questions, summarising parts of a text, clarifying word meanings and comprehending text passages and predicting what might come next in the text.

In addition to the comprehension strategies, Chiang (2016:2) advocates for the introduction of free voluntary reading (FVR). The FVR's approach is that learners should be encouraged to read out of the desire to read. It encourages reading in a low-anxiety and input-rich scenario. The researcher believes that the introduction of 'reading bags' as a technique towards developing reading habits will encourage learners to read. The technique also relates to FVR, known to improve reading habits and reading proficiency. An important aspect of using 'reading bags' is that it is anxiety free, as learners choose their own novels and read in their own time. It is through reading English novels that learners acquire the input they need for developing academic reading skills (Chiang 2016). These novels are easily available as they are provided through reading bags. The novels selected by learners enrich their vocabulary, grammar, speaking, listening and writing skills. In emphasising the importance of developing reading skills or habits, Stoller (2015:2) maintains that the best way to teach learners how to read is through reading itself. It is through the reading bags that students were encouraged to read.

\section{Problem-solving strategies}

Yuksel and Yuksel (2012) describe problem-solving strategies as those which require learners to adjust the reading rate, re-reading difficult texts and pausing to think about what they are reading. These strategies are important because they require learners to cross-examine the text before they can decipher any meaning. They are developed solely for the purpose of addressing problems emanating from the interaction with the text (Mokhtari \& Sheorey 2002).

\section{Support strategies}

The support strategies are basic support strategies students employ in comprehending the text, such as the use of a dictionary, taking notes, highlighting and underlining certain words or phrases (Mokhtari \& Sheorey 2002). These strategies serve as cues in enhancing the comprehension of a text where textual cues become incomprehensible to learners. Students get support by referring to the meaning of a word in the dictionary, highlighting important sections in the text and later cross-examining these for clearer understanding.

\section{Global reading strategies}

The global reading strategies are:

... intentional, carefully, planned techniques by which learners monitor or manage their reading, such as having a purpose in mind, previewing the text as to its length and organization, or using typographic aids and tables, and figures. (Mokhtari \& Sheorey 2002:12)

\section{Theoretical framework}

This study is underpinned by Vygotsky' theory of Social Learning (1978). The theory states that children learn language first to meet their social needs, after internalising. This leads to the development of higher order thinking and cognitive skills. This is what Vygotsky (1978) refers to as the Zone of Proximal Development (ZPD) (Savas 2009:397; Woolfolk 2010). The ZPD is described as:

\begin{abstract}
... the distance between the actual development level as determined by independent problem solving and the level of potential development as determined through problem solving under adult guidance or in collaboration with more capable peers. (Vygotsky 1978 as cited in Savas 2009:397)
\end{abstract}

The cognitive development of students is related to their performance at university. This is shown through Vygotsky's theory of ZPD which is related to the metacognition theories of language learning and teaching. The cognitive development of students is important in order for them to acquire Cognitive Academic Language Proficiency skills (Cummins 2009). A student who has reached the ZPD is ready to advance to a stage where he or she can venture into abstract thinking and higher order activities, with the help of someone who is the expert. The reader will then be able to comprehend texts through the application of the schema he or she has on the text. He or she either applies the bottom-up reading strategies or the top-down reading strategies in his or her writing (Nordin et al., 2013).

\section{Research questions}

The study aimed at answering the following research questions:

- What are the reading strategies employed by learners at secondary schools?

- Does the use of reading bags improve learners' reading strategies and reading habits?

\section{Research methodology}

A quantitative descriptive cross-sectional design was used to measure the shift in reading strategies after the use of the reading bags strategy to inculcate the love for reading. 


\section{Population and sampling}

A total of 155 learners in schools, identified by volunteered student-educators from the Capricorn district in Limpopo province, enlisted for the reading project. Learners were sampled out of their interest in the students' presentations from grade to grade on reading. These learners were from a historically disadvantaged background where English is used as a language of learning and teaching. However, they do not have the command of the English language to engage in their academic activities as required.

Fourteen student-educators volunteered to be ambassadors of the reading project and administered the project at their respective schools of choice during their teaching practicum in the first semester and second semester of the 2017 academic year. The schools were conveniently sampled as per the proximity to the student-educator's teaching practice choice.

\section{Instrument}

The survey on reading comprehension strategies adapted from Mokhtari and Reichard (2002) was used to collect data. The instrument is used for a large subject population, representing students with equivalent reading abilities, ranging from middle school to college. The instrument consists of 21 questions which ranged from support-reading and global reading and the problem-solving strategies. The internal reliability coefficient for its above subscales ranged from 0.89 to 0.93 and reliability for the total sample was 0.93 , showing a reasonably dependable measure of metacognitive awareness of reading strategies.

\section{Data collection}

A total of 185 questionnaires on metacognitive reading strategies (Mokhtari \& Sheorey 2002) were distributed to the sampled learners. These questionnaires were distributed before learners could be introduced to the reading bags and again after they have been introduced to the reading bags. In all, 155 questionnaires were returned and 30 were either misplaced or not returned at all.

\section{Procedure}

Data were collected in two phases: In phase one, the questionnaire was administered to identify reading strategies that learners used in their reading before they embarked on the reading project. Thereafter, different novels were distributed to learners as part of the 'reading bags' to encourage learners to read. These novels were chosen out of learners' interest and also their availability. Learners were given choices to read whatever novel or passage they came across, irrespective of whether it is in the bag or not (Stoller 2015:3). English language educators were also requested to look for novels in the library which might be of interest to the learners and place them in the bags.

In phase 2, which was in the second semester, the survey of reading strategies was again administered to learners by student-educators. All together 155 questionnaires were administered to the same group.

\section{Data analysis}

The analysis of data for the pre-intervention reading questionnaires was carried out focussing only on the reading strategies employed by learners. These were categorised into support reading strategies, global reading strategies and problem-solving strategies (Figure 1). The questionnaires for post-intervention reading were analysed for descriptive statistics using the Statistical Package for Social Sciences, version 17, for frequencies in percentages.

\section{Results \\ Descriptive results}

Figure 1 presents the pre-intervention questionnaire results before the reading bags were employed to inculcate good reading habits. The results show that the learners score $27 \%$ for global reading strategy, $48 \%$ for problem solving and $41 \%$ for support reading. This is different from the postintervention reading results as illustrated in the graph below where learners' performance improved.

Figure 2 represent learners' performance with regard to global reading strategies. There is an improvement of $72.3 \%$ in performance. The subquestions indicate the levels at which learners perform under the global reading strategies. The global reading strategies possess 13 subcategories which are learners' abilities to apply guessing when coming across new information; critically analysing and evaluating information; using contextual cues to help understand the text; using tables, figures and pictures in text to enhance understanding; being able to sift the important from the non-important; being familiar with text structure; and having a purpose in reading.

Figure 3 represents learners' performance when applying the problem-solving skills. Learners' performance has shown an improvement of $80 \%$. The problem-solving skills are important to learners in sharpening their thinking skills. They include the application of guessing, re-reading, picture formation, thinking, paying close attention to information, adjusting reading speed and reading slowly and carefully.

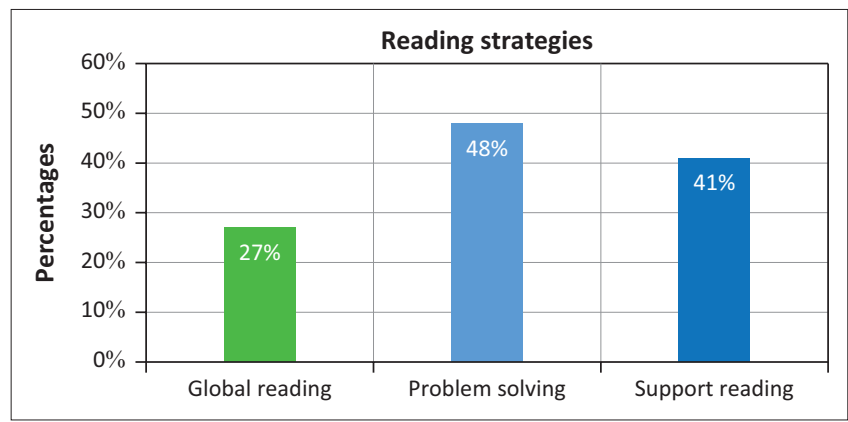

FIGURE 1: Reading strategies pre-intervention questionnaire results showing the metacognitive awareness of reading strategies. 


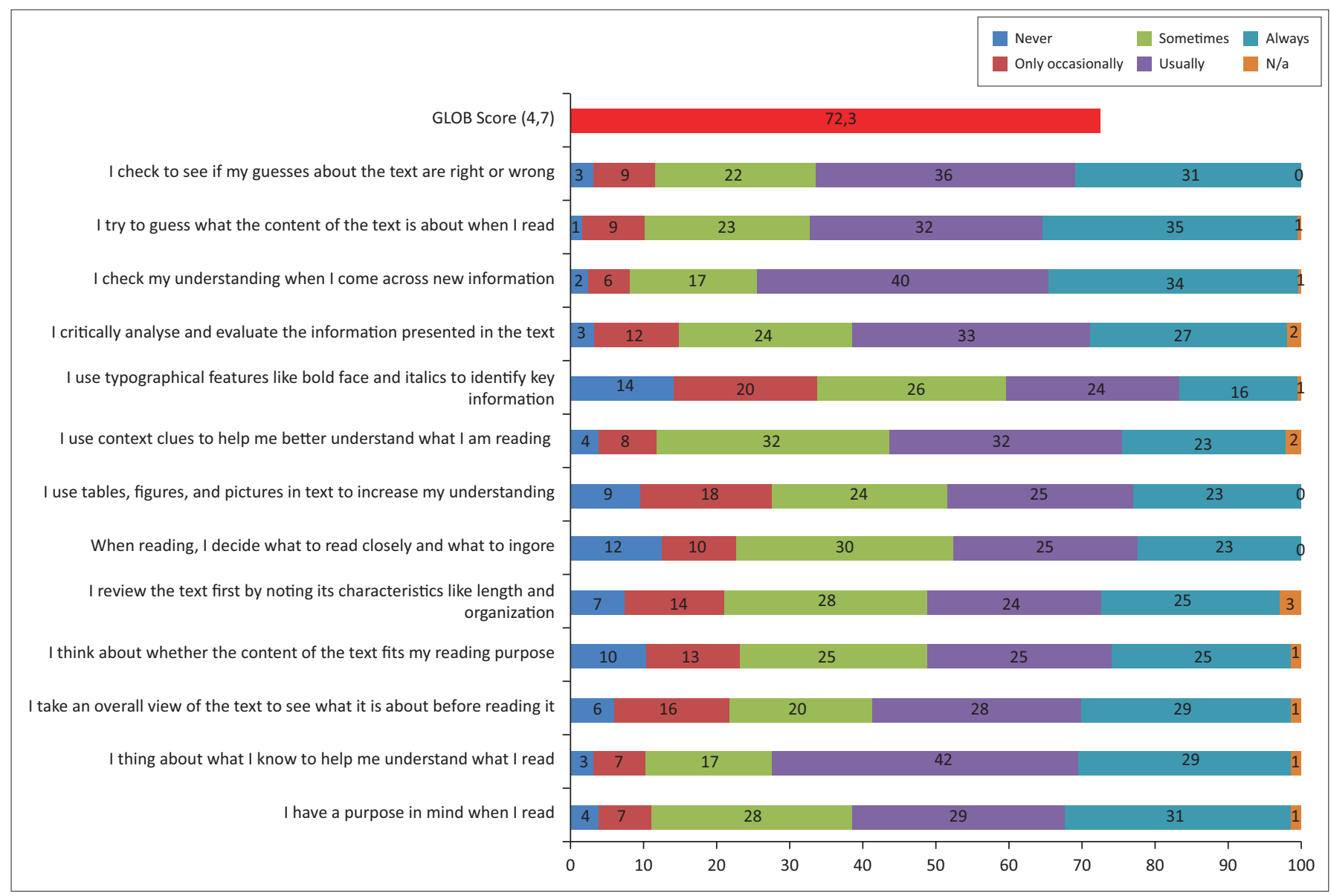

FIGURE 2: Post-intervention questionnaire results showing the metacognitive awareness of reading strategies inventory: Global Reading Strategies.

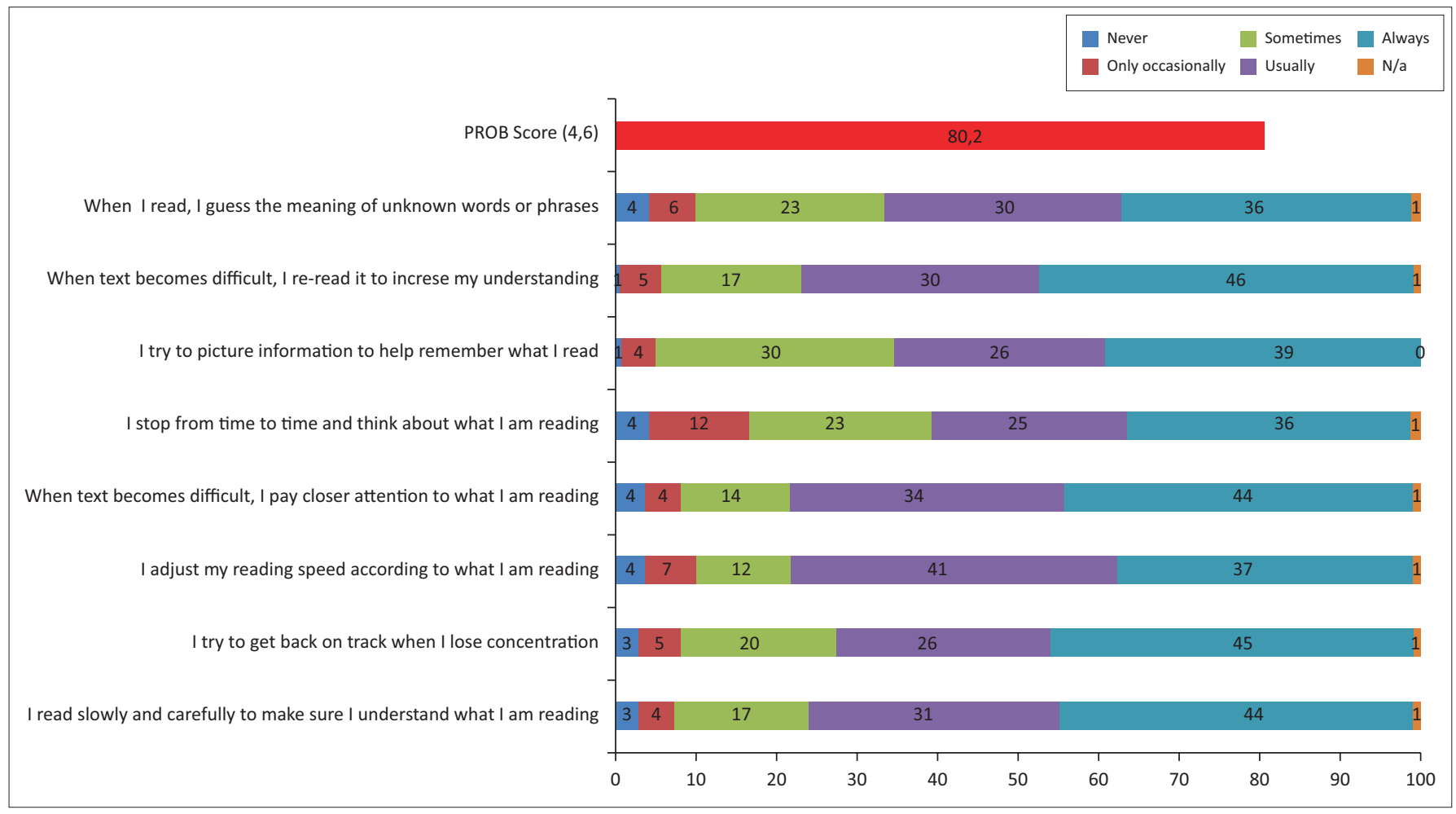

FIGURE 3: Post-intervention questionnaire results showing the metacognitive awareness of reading strategies inventory: Problem-Solving Strategies. 


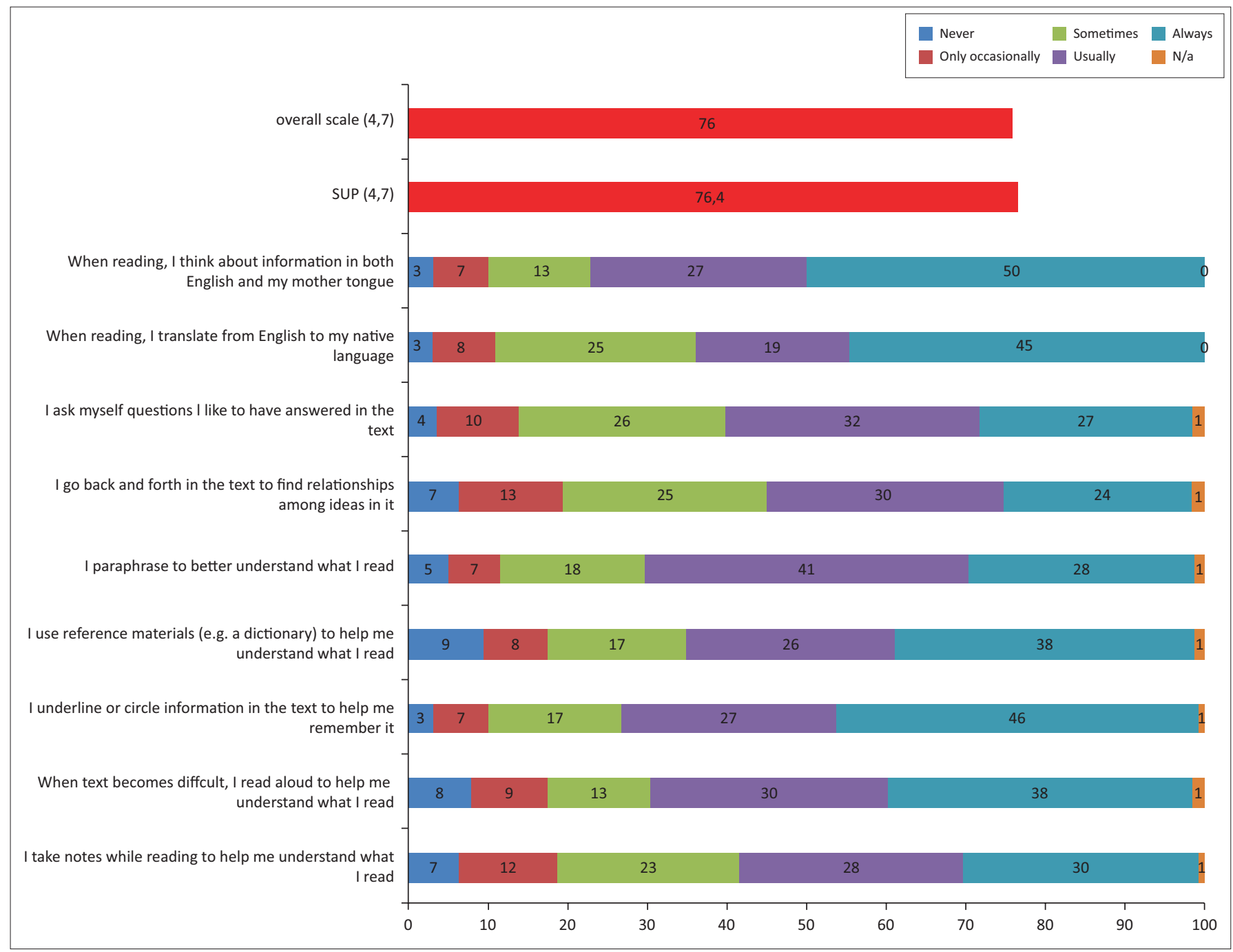

FIGURE 4: Post-intervention questionnaire results showing the metacognitive awareness of reading strategies inventory: Support Reading Strategies.

Figure 4 represents the support reading strategies employed by learners. Learners performed at $70 \%$, which displayed an improvement. The use of support reading strategies includes the application of thinking, translating, asking oneself, cross-examine the text, paraphrasing, referencing materials, underline or circle information, taking notes and reading aloud skills.

\section{Discussion}

The preliminary results show that learners were aware of the strategies they use in their reading. This is shown by a high percentage of the use of the problem-solving strategies (48\%). Their performance in global and support reading skills displayed a low performance of $27 \%$ and $41 \%$, respectively. The results of these strategies are in response to the first research question on what reading strategies learners in high schools employ. The preliminary results indicate learners are aware of these strategies, even though their percentages are low. The intervention through the introduction of the reading bags has led to an improvement in learners' reading strategies. Learners reported a high percentage of $72.3 \%$ for global reading strategies, $80.2 \%$ for problem-solving strategies and $76.4 \%$ for support reading strategies. The results indicate the positive effect of using reading bags to enhance learners' reading habits and develop useful strategies in academic reading. These results are also in agreement with the literature reviewed on reading (Chiang 2016; Stoller 2015). This is also evident from the comments given by learners during their interaction with student-educators.

These results are in agreement with the results by Mokhtari and Sheorey (2002) and Yuksel and Yuksel (2012) on the use of problem-solving strategies as being critical to the reading process. The results are also in agreement with the results of Zhang and $\mathrm{Wu}$ (2009), which indicated that the use of learners' global, support and problemsolving skills is positively linked to learners' proficiency level in English skills and fosters good reading skills. It is, however, worth noticing the improvements in the post-reading test as shown by the percentages in all strategies.

The results of this study also confirm what Ismail and Tawalbeh (2015) maintained when arguing that metacognitive 
reading skills engage learners in a high level of metacognition, or monitoring of their own thinking, during the reading process. The global reading skills' results indicate the correlation between the learners' application of the thinking skills when interrogating their texts. The reading programme had a positive impact on learners' performance as shown in the improved performance in the support, global and problem-solving strategies.

\section{Conclusions and recommendations}

The main objective of the study was to investigate the metacognitive reading strategies employed by learners at the selected schools. The study also set to investigate the effects of the introduction of the reading bags project as an intervention strategy to encourage learners to read. Preliminary results from the administration of the metacognitive reading strategies found that learners do apply reading strategies, even though their responses displayed a low percentage. The administration of the metacognitive reading awareness strategies inventory after the intervention programme displayed an improved performance in the application of the reading strategies (Appendix 1).

The researchers would like to recommend that learners should be encouraged to read through programmes which are interesting to them. This will inculcate good reading habits at a young age, which will help to improve their use of reading strategies and overall reading proficiency.

\section{Acknowledgements Competing interests}

The authors declare that they have no financial or personal relationships which may have inappropriately influenced them in writing this paper.

\section{Authors contributions}

M.N. made the conceptualization of the study and wrote the first draft. P.K. did literature review and edited the article. All authors read and approved the final manuscript.

\section{References}

Acheaw, M.O.\& Larson, A., 2014, 'Reading habits among students and its effect on academic performance: A study of students of Koforidua Polytechnic', Library Philosophy and Practice (e-journal), Paper 1130, viewed n.d., from http:// digitalcommns.unl.edu/libphilprac/1130

Annual National Assessment, 2014, Report on the ANA of 2013. Pretoria: Government Printers, viewed 15 July 2017, from http://www.gov.co.za

Arkarsu, O. \& Harputlu, L., 2014, 'Perceptions of EFL students toward Academic Reading', The Reading Matrix 14(1),315-327

Boakye, N., 2017, 'Extensive reading in a tertiary reading programme: Students' accounts of affective and cognitive benefits', Reading \& Writing 8(1), a153. https://doi.org/10.4102/rw.v8i1.153

Cekiso, M. \& Madikiza, N., 2014, 'Reading strategies used by Grade 9 English Second Language learners in a selected school', Reading and Writing 5(1), Art. \#42, 7 pages. https://doi.org/10.4102/rw.v5i1.42

Chiang, M., 2016, 'Effects of varying text difficulty levels on second language (L2) reading attitudes and reading comprehension', Journal of Research in Reading $39,448-468$.
Chizwina, S.R., 2011, An exploratory investigation into the status of reading promotion projects in South Africa, University of Pretoria, Pretoria.

Cummins, J., 2009, 'Multilingualism in the English-language classroom: Pedagogical considerations', TESOL Quartely 43(2), 317-331. https://doi.org/10.1002/j.15457249.2009.tb00171.x

Day, R. \& Bamford, J., 2004, Extensive reading in the second language classroom, Cambridge University Press, London.

Department of Education (DoE), 2008, National Reading Strategy (NRS), Department of Education, Pretoria, viewed 15 July 2017, from http://www.gov.co.za

Gallagher, K., 2009, Readicide: How schools are killing reading and what you can do about it, Stenhouse Publishers, Portsmouth.

Grabe, W., 1991, 'Current developments in second language reading research', Tesol Quarterly 25(3), 22-41. https://doi.org/10.2307/3586977

Grabe, W. \& Stoller, F., 2002, Teaching and researching reading, Pearson Education, London.

Greene, A. \& Serro, W.T., 2015, 'Encouraging critical thinking and professional reading with literacy bags', The Open Communication Journal 9, 65-71. https://doi.org/ $10.2174 / 1874916$ X01509010065

Henia, N., 2003, 'Evaluating the effectiveness of metacognitive strategy training for reading research articles in an ESP context', English for Specific Purposes 22(2003), 387-417. https://doi.org/10.1016/S0889-4906(03)00017-6

Ismail, N.M., \& Tawalbeh, T.I., 2015, 'The effect of Iranian EFL learners' awareness of reading comprehension strategies on their motivation to read, International Journal of English Language Education 1(1), 162-178.

McNamara, D.S., 2007. Reading comprehension strategies: Theories, interventions, and technologies, Lawrence Erlbaum Associates, New York.

Molotja, T.W., 2016, 'Investigation of academic reading skills of science foundation students at university of Venda', Unpublished PhD thesis submitted in fulfilment of the requirements for the degree of Doctor of Philosophy in English

Mokhtari, K. \& Reichard, C.A., 2002, 'Assessing students' metacognitive awareness of reading strategies', Journal of Educational Psychology 94(2), 249-259. https://doi. org/10.1037/0022-0663.94.2.249

Mokhtari, K., Reichard, C.A. \& Gardner, A., 2009, 'The impact of internet and television use on the reading habits and practices of college students', Journal of Adolescent \& Adult Literacy 52 (7), Tyler, Texas. https://doi.org/10.1598/JAAL.52.7.6

Mokhtari, K. \& Sheorey, R., 2002, 'Measuring ESL students awareness of reading strategies', Journal of Developmental Education 25(3), 2.

Negretti, R. \& Kuteeva, M., 2011, 'Fostering metacognitive genre awareness in L2 academic reading and writing: A case of study of pre-service English teachers', Journal of Second Language Writing 20(2011), 95-110. https://doi.org/10.1016/j. jslw.2011.02.002

Nhapulo, M.A, Simon, E. \& Van Herreweghe, M., 2017, 'Enhancing academic reading skills through extensive reading', Southern African Linguistics and Applied Language Studies 35(1), 17-40, viewed n.d., from http://hdl.handle.net/1854/ LU-852051. 2017/03/20

Nordin, N.M., Rashid, S.M., Zubir, S.I.S. \& Sadjirin, R., 2013, 'Differences in reading strategies: How ESL learners really read', Procedia - Social and Behavioural Sciences 90(2013), 468-477. https://doi.org/10.1016/j.sbspro.2013.07.116

Palani, K.K., 2012, 'Promising reading habits and creating literate society', International Reference Research Journal 2(1), 91-98.

Pammu, A., Amir, Z. \& Maasum, T., 2014, 'Metacognitive reading strategies of less proficient tertiary learners: A case study of EFL learners at a public university in Makassar, Indonesia', Procedia - Social and Behavioural Sciences 118, 357-364. https://doi.org/10.1016/j.sbspro.2014.02.049

Progress in International Reading Literacy Study (PIRLS), 2016, National Centre for Education Statistics, viewed n.d., from http://www.nces.ed.gov/surveys/pirls/ pirls2011.asp.2017/01/22

Republic of South Africa, 2011, National Planning Commission: National Development Plan: Vision for 2030, viewed n.d., from https://www.gov.za/sites/www.gov.za/ files/devplan_2.pdf

Ralenala, M.F., 2003, 'Reading behaviour of first-year physics students at the University of the North', PhD thesis, Rand Afrikaans University.

Ralenala, M.F., 2005, 'Readers, texts, and reading process models: The difficulties of comprehending science text by English second language university students', Journal of Content Area Reading 1.

Routman, R., 2003, Reading essentials. The specifics you need to teach reading well, Heinemann, Cape Town.

Savas, B., 2009, 'Role of functional academic literacy in ESP teaching: ESP teacher training in Turkey for sustainable development', The Journal of International Social Research 2(9), 395-406. Fall 2009.

Scott, L. \& Saaiman, E., 2016, 'Promoting reading skills or wasting time? Students' perceived benefits of reading in an intermediary programme at the Vaal University of Technology', Reading \& Writing -Journal of the Reading Association of South Africa 2079-8245.

Shafie, L. \& Nayan, S., 2011, 'The characteristics of struggling university readers and instructional approaches of academic reading in Malaysia', International Journal of Human Sciences 8(1), viewed n.d., from http://www.insanbilimleri.com/en. 2017/06/23.

Stoller, F.L., 2015, 'Viewing extensive reading from a different vantage points', Reading in a Foreign Language 27(1), 152-159.

Stone, R.J., 2013, 'A teacher's guide to academic reading: Focusing on the academic reading demands of ESL learners', All Thesis and Dissertations, Paper 3882. London. 
Vygotsky, L.S., 1978, Mind in society: The development of higher mental process, Harvard University, Cambridge, MA.

Walundari, E., 2016, 'Developing curriculum and tasks for teaching reading', Journal of English and Education 6(2). 23-35.https://doi.org/10.20885/jee.vol6.iss2. art3

Woolfolk, A., 2010, Educational psychology, 11th edn., Pearson Education International, Columbus, Ohio.
Yuksel, I. \& Yuksel, I., 2012, 'Metacognitive awareness of academic reading strategies', Procedia-Social and Behavioural Sciences 31(9), 894-898. https://doi. org/10.1016/j.sbspro.2011.12.164

Zhang. L.J. \& Wu, A., 2009, 'Chinese senior high school and EFL students' metacognitive awareness and reading-strategy use', Reading in a Foreign Language 21(1), 37-59.

Zohar, A. \& Dori, Y.J., 2012, Metacognition in science, 3(Springer 2012), Springer Dordrecht Heidelberg London. 


\section{Appendix 1}

Metacognitive awareness of Reading Strategies Inventory (Version 1.0)

Name

Gender

Age

Directions: Listed below are statements about what people do when they read academic or school-related materials such as textbooks or library books.

Five numbers follow each statement $(1,2,3,4,5)$, and each number means the following:

- 1 means 'I never or almost never do this'.

- 2 means 'I do this only occasionally'.

- 3 means 'I sometimes do this' (about $50 \%$ of the time).

- 4 means 'I usually do this'.

- 5 means 'I always or almost always do this'.

After reading each statement, circle the number $(1,2,3,4$, or 5$)$ that applies to you using the scale provided.

Please note that there are no right or wrong answers to the statements in this inventory.

TABLE 1-A1: Type strategy scale

\begin{tabular}{|c|c|c|c|c|c|c|}
\hline GLOB 1 & I have a purpose in mind when I read & 1 & 2 & 3 & 4 & 5 \\
\hline SUP 2 & I take notes while reading to help me understand what I read & 1 & 2 & 3 & 4 & 5 \\
\hline GLOB 3 & I think about what I know to help me understand what I read & 1 & 2 & 3 & 4 & 5 \\
\hline GLOB 4 & I preview the text to see what it's about before reading it & 1 & 2 & 3 & 4 & 5 \\
\hline SUP 5 & When text becomes difficult, I read aloud to help me understand what I read & 1 & 2 & 3 & 4 & 5 \\
\hline SUP 6 & I summarise what I read to reflect on important information in the text & 1 & 2 & 3 & 4 & 5 \\
\hline GLOB 7 & I think about whether the content of the text fits my reading purpose & 1 & 2 & 3 & 4 & 5 \\
\hline PROB 8 & I read slowly but carefully to be sure I understand what I'm reading & 1 & 2 & 3 & 4 & 5 \\
\hline SUP 9 & I discuss what I read with others to check my understanding & 1 & 2 & 3 & 4 & 5 \\
\hline GLOB 10 & I skim the text first by noting characteristics like length and organization & 1 & 2 & 3 & 4 & 5 \\
\hline PROB 11 & I try to get back on track when I lose concentration & 1 & 2 & 3 & 4 & 5 \\
\hline SUP 12 & I underline or circle information in the text to help me remember it & 1 & 2 & 3 & 4 & 5 \\
\hline PROB 13 & I adjust my reading speed according to what I'm reading & 1 & 2 & 3 & 4 & 5 \\
\hline GLOB 14 & I decide what to read closely and what to ignore & 1 & 2 & 3 & 4 & 5 \\
\hline SUP 15 & I use reference materials such as dictionaries to help me understand what I read & 1 & 2 & 3 & 4 & 5 \\
\hline GLOB 17 & I use tables, figures, and pictures in text to increase my understanding & 1 & 2 & 3 & 4 & 5 \\
\hline PROB 18 & I stop from time to time and think about what I'm reading & 1 & 2 & 3 & 4 & 5 \\
\hline GLOB 19 & I use context clues to help me better understand what I'm reading & 1 & 2 & 3 & 4 & 5 \\
\hline SUP 20 & I paraphrase (restate ideas in my own words) to better understand what I read & 1 & 2 & 3 & 4 & 5 \\
\hline PROB 21 & I try to picture or visualise information to help remember what I read & 1 & 2 & 3 & 4 & 5 \\
\hline GLOB 22 & I use typographical aids like boldface and italics to identify key information & 1 & 2 & 3 & 4 & 5 \\
\hline GLOB 23 & I critically analyse and evaluate the information presented in the text & 1 & 2 & 3 & 4 & 5 \\
\hline
\end{tabular}

Source: Adapted from Mokhtari, K. \& Sheorey, R., 2002, 'Measuring ESL students awareness of reading strategies', Journal of Developmental Education 25(3), 2 